\title{
The Characterization of the Esterases of Human Plasma
}

\author{
By D. H. ADAMS AND V. P. WHITTAKER, Department of Biochemistry, University of Oxford
}

(Received 30 March 1948)

The enzymes which catalyze the hydrolysis of esters of relatively low molecular weight have been divided into three main types: aliphatic esterases ('aliesterases'), which hydrolyze aliphatic esters such as methyl butyrate and tributyrin; specific or 'true' cholinesterases, which hydrolyze acetylcholine but not certain aliphatic esters; and non-specific or 'pseudo'-cholinesterases, which hydrolyze both acetylcholine and aliphatic esters. They are distinct from the lipases, which, however, may also hydrolyze the simpler triglycerides, and from other, often illdefined esterases, such as the sterol esterases and lecithinases.

The characterization of these enzymes is made difficult both by their overlapping specificity and by the fact that two or more types of esterase may occur together in biological material. Considerable progress has, however, lately been made by the use of synthetic substrates, the hydrolysis of which appears to be specific for certain classes of esterase (Mendel, Mundell \& Rudney, 1943), and by means of specific inhibitors, several very potent examples of which have been discovered in recent chemical warfare research. Thus the fluorophosphonates such as diisopropyl fluorophosphonate (DFP) inhibit pseudocholinesterases very powerfully and true cholinesterase to a considerably less degree (Mazur \& Bodansky, 1946; Mendel \& Hawkins, 1947). Thompson (1947) and Adams \& Thompson (1948) have shown that another chemical warfare agent, di(2-chloroethyl)methylamine (DDM), powerfully inhibits cholinesterases, the 'specific' cholinesterase of brain and erythrocytes being this time the more sensitive.

The differential nature of the inhibition by DFP and DDM is well brought out by measuring the ratio of the concentrations of the two inhibitors which are required to give $50 \%$ inhibition of the system under identical conditions. The values obtained for this ratio (the DDM/DFP $I_{50}$ ratio) for the 'specific' cholinesterases of human brain and erythrocytes were of the same order of magnitude (450 and 600 respectively); the value for the cholinesterase of human plasma which, as pointed out below, is probably a non-specific cholinesterase, was widely different, being about $2.5 \times 10^{5}$.

There would thus seem to be here a useful additional method for the characterization of esterases which might be used, without the necessity for enzyme purification, to decide whether a particular esterase activity shown by different tissues is due to essentially the same enzyme or to widely different enzymes; it could also be applied to the related problem of deciding whether a number of different esterase activities shown by the same tissue is due to a single enzyme or not.

The present investigation has been made with the object of testing this second application of the method and of ascertaining what variations in the $I_{50}$ ratio can be regarded as significant. We have chosen as our enzyme source human plasma, which has been considered by previous investigators to contain a single non-specific esterase which is uncomplicated by the presence of a second enzyme and hydrolyzes acetyl-and benzoyl-choline, glyceryl tributyrate and triacetate, and methyl butyrate, but not acetyl- $\beta$-methylcholine.

Thus Vahlquist (1935) found that the acetylcholine and tributyrin esterase activities of human plasma were not separated by cataphoresis, that the inhibitory effects on them of atoxyl, eserine and quinine were of the same order, and that there was a significant correlation between them in different subjects, both normal and diseased, and in the same subject at different times. He also noted that methyl butyrate hydrolysis was similarly inhibited by atoxyl and eserine but was stimulated by quinine; the inhibition data were not, however, very extensive or satisfactory.

Easson \& Stedman (1937), although critical of Vahlquist, agreed that acetylcholine, tributyrin and methyl butyrate esterase activities are approximately equally sensitive to eserine. They also performed summation experiments which, they state, were consistent with the conclusion that only one esterase is present. Richter \& Croft (1942) confirmed and extended Vahlquist's results without, however, using any new techniques. They showed a significant correlation between the rates of hydrolysis of acetylcholine and tributyrin, and of acetylcholine and methyl butyrate, by human serum, which was unchanged by partial denaturation and absorption. They found that the hydrolysis of all three substrates was completely inhibited by $10^{-5} \mathrm{M}$ eserine. They also confirmed the puzzling stimulating effect of quinine on methyl butyrate hydrolysis.

Mendel et al. (1943) found that human plasma hydrolyzes benzoylcholine. It also hydrolyzes acetyl- $\beta$-methylcholine, but only very slowly (1-2\% of the rate with acetylcholine). In this it resembles the purified cholinesterase of horse serum, but differs from the enzyme of the erythrocytes and brains of a wide range of species. It is therefore classified by these workers as a pseudo-cholinesterase.

Early references to a serum lipase (e.g. Hanriot, 1898) do not, apparently, refer to a genuine lipase activity on true fats, but to the esterase activity of serum. Thus Vahlquist states that plasma is 'practically without effect on ordinary 
fats' and Richter \& Croft (1942) conclude that there is 'no evidence for a serum lipase in normal human serum'.

The present work falls into two parts. In the first; we have used a statistical method for determining the $I_{50}$ ratio for representative choline and noncholine esters which enables us to obtain an estimate of the probable range of the ratio for each substrate, and we have found that the values are closely similar. This and the further evidence provided by summation experiments have led us to conclude that acetyl-and benzoyl-choline, tributyrin and triacetin are all hydrolyzed in plasma by one enzyme, a nonspecific or pseudo-cholinesterase. In the course of this work, however, we obtained evidence for the presence in plasma of a small amount of a second enzyme, insensitive to DFP and DDM, capable of splitting aliphatic esters such as tributyrin and triacetin and also responsible for a small lipase-like activity of plasma towards such substrates as triolein. In the second part we describe a method of obtaining a preparation of the DFP-sensitive enzyme free from this second enzyme.

\section{METHODS}

Source of plasma. The plasma used in most of the experiments was obtained by centrifuging fresh citrated blood provided by the E.M.S. Blood Transfusion Service; in the remainder, the blood was drawn from laboratory volunteers, and sodium citrate $(0.1 \%)$ added. Transfusion plasma was found to be an excellent enzyme source, different samples having a high and fairly constant activity. Plasma was stored at $0^{\circ}$, and showed little loss of activity in 3-4 weeks.

Substrates. The following esters were used. Choline esters: acetylcholine chloride (ACh) (British Drug Houses Ltd.); benzoylcholine bromide (BCh) (a preparation kindly furnished by Dr A. H. Ford-Moore, Experimental Station, Porton); aliphatic esters: glyceryl tributyrate (TB); glyceryl triacetate (TA); methyl butyrate (MeB) (all from British Drug Houses Ltd.); glyceryl trioleate (TO) (as olive oil).

The choline esters were used in the form of a freshly prepared solution in $0.024 \mathrm{M}-\mathrm{NaHCO}_{3}$; the aliphatic esters were pipetted directly into the side bulbs of the reaction flasks and covered with bicarbonate solution. Owing to their sparing solubility they were present in the reaction mixture wholly or partly as an emulsion; the concentrations given in later sections are those that would have been attained had all the added ester dissolved. Careful purification of TB and TA before use was found to be essential, especially in the summation experiments. This was accomplished by washing with $\mathrm{NaHCO}_{3}$ solution and water saturated with $\mathrm{NaCl}$, drying over anhydrous $\mathrm{Na}_{2} \mathrm{SO}_{4}$ and distilling in vacuo, the middle fraction being used.

Preliminary experiments showed that under our conditions a maximum or nearly maximum rate of hydrolysis, which remained constant during the experimental period, was obtained with concentrations of $\mathrm{ACh}$ and $\mathrm{BCh}$ of $0.006 \mathrm{M}$ or higher, and with 0.1M-TB, TA and MeB, and these concentrations were used throughout the work.

Inhibitors. Di-(2 - chloroethyl)methylamine hydrochloride (DDM); diisopropyl fluorophosphonate(DFP) (both from the Experimental Station, Porton). These were used as freshly prepared solutions in bicarbonate.

Estimation of esterase activity. Esterase activity was determined manometrically by Ammon's (1933) adaptation of the Warburg technique, in which hydrolysis of the ester is followed by measurement of the $\mathrm{CO}_{2}$ liberated from a

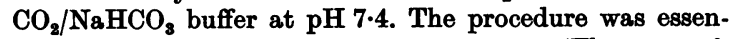
tially that described in our previous papers (Thompson \& Whittaker, 1944; Adams \& Thompson, 1948), the substrate being added to the side bulbs of the Warburg flasks, and plasma, inhibitor and sufficient $0.2 \% \mathrm{NaHCO}_{3}$ to give a final volume of $3 \mathrm{ml}$. to the main compartment. The flasks were then gassed with $95 \% \mathrm{~N}_{2}+5 \% \mathrm{CO}_{2}$, equilibrated at $38^{\circ}$ and the substrate tipped in. Esterase activity is recorded as $\mu \mathrm{l}$. $\mathrm{CO}_{2}$ evolved $/ 30 \mathrm{~min} . / \mathrm{ml}$. plasma.

\section{RESULTS}

\section{Experiments with unpurified plasma}

Enzymic activity of plasma. Table 1 shows some collected data of the rate of hydrolysis of $\mathrm{ACh}, \mathrm{BCh}$, TB, TA and MeB in the presence of plasma. Each line of the table relates to the same plasma. The figures given are the average of different experiments, even when, as with ACh and BCh, the concentration of substrate was not always the same,

\section{Table 1. The relative rates of hydrolysis of $A C h, B C h, T B, T A$ and $M e B$ in presence of plasma esterase}

(Average values for different samples of plasma are given, the figures in parenthesis being the number of experiments averaged. Concentrations: $\mathrm{ACh}, \mathrm{BCh}, 0.006-0.03 \mathrm{M} ; \mathrm{TB}, \mathrm{TA}, \mathrm{MeB}, 0.1 \mathrm{M}$.)

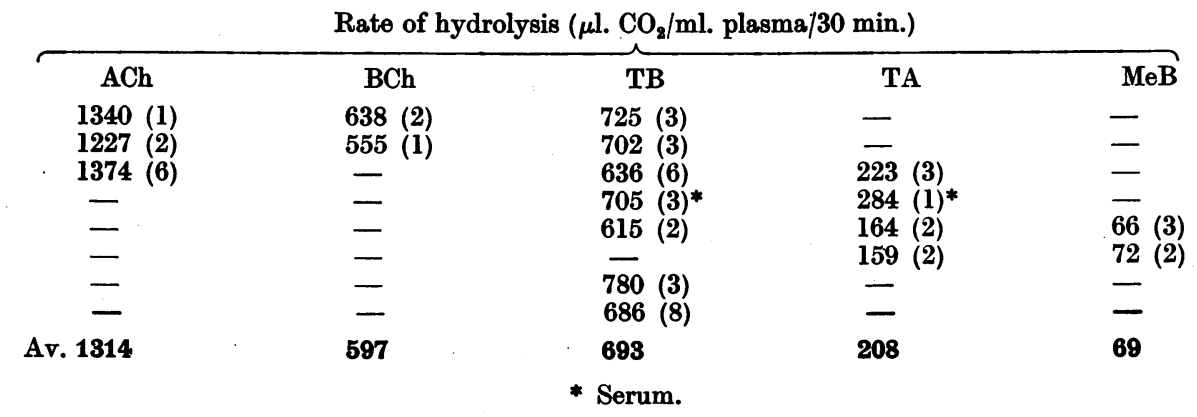


since this was invariably such as to give a steady maximum rate of hydrolysis. The concentration of plasma varied; it was greater with the less rapidly hydrolyzed substrates in order to give conveniently measurable $\mathrm{CO}_{2}$ evolutions.

It will be seen that $\mathrm{ACh}$ is the most rapidly hydrolyzed ester, that BCh and TB are split at about half, and TA and MeB at about one-seventh and one-twentieth, the rate with ACh. It should be noted, however, that the ratios of the average activities of different plasmas are not strictly comparable as there were varying losses in activity during storage.

Plasma appears to cause a small catalytic hydrolysis of triolein (Table 2), which is lost on heating, and is proportional to the amount of plasma present.

\section{Table 2. Rate of hydrolysis of triolein by plasma}

(Figures in brackets are number of experiments averaged; columns to be read independently.)

Rate of hydrolysis

$\begin{array}{ll}\overbrace{0.03 \mathrm{M}}^{\left(\mu \mathrm{l} . \mathrm{CO}_{2} / \mathrm{ml} . \text { plasma } / 20 \mathrm{~min} .\right)} \\ 33 & \mathbf{0 . 0 7 \mathrm { M }} \\ 27 & 51(3) \\ 33(2) & 59 \\ - & 48(2) \\ - & 55 \\ \text { * Measured over } & \mathbf{2 5} \mathrm{min} .\end{array}$

The rate of the catalyzed reaction was found to decrease rapidly after the substrate had been tipped into the reaction mixture, becoming nearly zero after $30 \mathrm{~min}$. Changes in plasma or substrate concentration did not, under our conditions, produce a steady rate of hydrolysis, but the rate did appear to be increased when the amount of triolein was increased from 90 to $210 \mathrm{mmol} . / 3 \mathrm{ml}$, even though most of the substrate was present as an emulsion. If the enzyme responsible for TO hydrolysis can act, like other lipases, at oil-water interfaces, a simple relation between substrate concentration and rate of hydrolysis cannot be expected.

Experiments with inhibitors. The hydrolysis of ACh, BCh, TA and TB is inhibited very strongly by both DFP and DDM, though in much lower concentrations by the former. We have determined the $I_{50}$ inhibitor concentrations and the $I_{50}$ ratio for these substrates by a method which gives an estimate of the probable ranges of their values.

The principle is as follows. If an assumption is made as to the form of the relationship between the percentage inhibition $i$ and the inhibitor concentration $I$, suitable transformations of the variables $i$ and $I$ into other variables $x$ and $y$ will give a linear relation between $x$ and $y$. The line of best fit for the experimental values for $x$ and $y$ may now be computed. From this may be calculated the most probable value and the range of probable values of $y_{50}$, the value of $y$ corresponding to $x_{50}$, the value which $x$ assumes at $50 \%$ inhibition. Suitable combinations of these $y_{50}$ values for the two inhibitors lead to estimates of the most probable value and the range of probable values of the $I_{50}$ ratio.

The simplest relation between $i$ and $I$ which appeared to fit the data is given by the expression

$$
i=\frac{b I}{1+a I} \text {. }
$$

This relation, although advanced empirically, can be derived theoretically by making certain assumptions, the chief of which is that the enzyme $E$ and inhibitor $I$ form a single dissociable complex $E I$ which participates in the equilibrium

$$
E+I \rightleftharpoons E I \text {. }
$$

The legitimacy of applying this equilibrium to DDM and DFP is considered in the discussion.

If, in equation (1), $i$ is put equal to $1 / x$ and $I$ to $1 / y$, the expression is transformed into the linear relation

$$
y=b x-a .
$$

The best estimates of $b$ and $a$ may then be calculated by standard statistical procedure, and from them the most probable value of $y_{50}$ (the value of $y$ for which $x=1 / 50$ ), together with its standard error 8 , can readily be obtained.

The best estimate of the $I_{50}$ ratio (DDM/DFP) is $y_{50} / y_{50}^{\prime}$, where the primed symbol refers to DDM and the unprimed to DFP; the probable range of estimates of the $I_{50}$ ratio can be obtained as follows.

The upper and lower limits of the range of $y_{60}$ values outside which only $20 \%$ of estimates may be expected to lie is given by $y_{50} \pm t s$, where $t$ is the appropriate value of Student's ratio corresponding to $P=0 \cdot 2$. Thus, the probability of obtaining an $I_{50}$ ratio in which both numerator and denominator lie outside the $20 \%$ probability limits is $(0 \cdot 2)^{2}$, and there are four such ranges of ratio, the probability of occurrence of a value within any one being $0 \cdot 2)^{2} / 4$, i.e. $0 \cdot 01$.

These four ranges of the ratio are
(1) $\frac{<\left(y_{50}-t s\right)}{>\left(y_{50}^{\prime}+t^{\prime} s^{\prime}\right)}$,
(2) $\frac{<\left(y_{50}-t s\right)}{<\left(y_{50}^{\prime}-t^{\prime} s^{\prime}\right)}$,
(3) $\frac{>\left(y_{50}+t s\right)}{>\left(y^{\prime}{ }^{\prime}+t^{\prime} s^{\prime}\right)}$,
(4) $\frac{>\left(y_{50}+t s\right)}{<\left(y_{50}^{\prime}-t^{\prime} s^{\prime}\right)}$.

Inspection shows that (1) is the lowest range within which only $1 \%$ of estimates is likely to fall, while (4) is the highest range. The limits outside which only $2 \%$ of values of the $I_{50}$ ratio may be expected to fall are therefore

$$
\frac{y_{50}-t s}{y_{50}^{\prime}+t^{\prime} 8^{\prime}} \text { and } \frac{y_{50}+t s}{y_{.50}^{\prime}-t^{\prime} 8^{\prime}} \text {, }
$$

ranges (2) and (3) lying between these limits.

This treatment is based on the assumption that the two $y_{50}$ estimates are statistically independent; if they are not, the method overestimates the probable range of values of the $I_{50}$ ratio.

Fig. 1 shows typical reciprocal plots for the inhibition of BCh by DDM and DFP; the complete data are presented in Table 3. All determinations 
giving an average inhibition less than $15 \%$ have been excluded from the calculations, since it was found that inhibitions of these low values were not reproducible. Table 4 shows the most probable $y_{50}$ values for the various substrates and inhibitors, their standard errors and the corresponding $I_{50}$ values; and Table 5 shows the most probable values for the $I_{50}(\mathrm{DDM} / \mathrm{DFP})$ ratios, and the upper and lower limits of each ratio outside which only $2 \%$ of estimates would be expected to fall. It will be noted in Table 5 that the values for the $I_{50}$ ratios for all substrates lie close together, any variation being well within the range of possible variation of any one substrate. On the other hand, as is shown in Table 4, the results for the $I_{50}$ values given by either inhibitor vary considerably from substrate to substrate.

In contrast to the behaviour of the substrates so far mentioned, the triolein hydrolysis was uninhibited by both DFP and DDM, even in the highest concentrations used, $3.6 \times 10^{-6} \mathrm{M}$ and $1.75 \times 10^{-3} \mathrm{M}$ respectively.

Certain anomalies were noted at high DFP concentrations. Concentrations which were considerably in excess of those required to produce a practically complete inhibition of ACh hydrolysis failed to do so with the aliphatic substrates, at any rate during the first $10 \mathrm{~min}$. of the measurements, i.e. until after about 35 min. after mixing enzyme

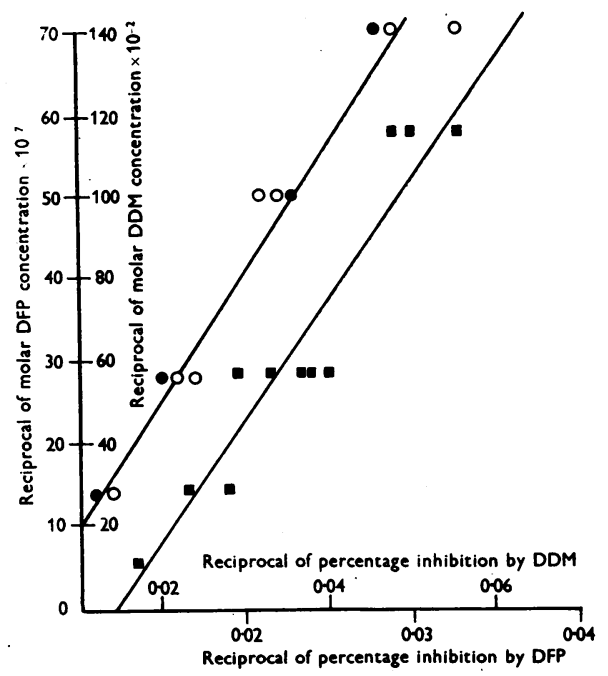

Fig. 1. The inhibition by DFP and DDM of the hydrolysis of $0.006 \mathrm{M}$-benzoylcholine by human plasma $(0.2 / 3 \mathrm{ml}$.). Ordinates: reciprocal of inhibitor concentrations; abscissae: reciprocal of percentage inhibition. The straight lines are the regressions of $y$ on $x$. Circles: experiments with DFP, black circles denoting two coincident points; squares: experiments with DDM. ( $\mathrm{DFP}=$ diisopropyl fluorophosphate, DDM = di-(2-chloroethylmethylamine.)

\section{Table 3. The inhibition of plasma esterases by DFP and $D D M$}

(Concentration of plasma: ACh, BCh and TB experiments, $0.2 \mathrm{ml} . / 3 \mathrm{ml}$.; TA experiments, $0.5 \mathrm{ml} . / 3 \mathrm{ml}$. Concentration of substrates: $\mathrm{ACh}, \mathrm{BCh}, 0.006 \mathrm{M} ; \mathrm{TB}, \mathrm{TA}, 0.1 \mathrm{M}$.)

\section{DFP}

concentration

$\times 10^{9}$

(M)

0.9

$1 \cdot 0$

1.42

$1 \cdot 8$

$2 \cdot 16$

3.0

$3 \cdot 6$

$5 \cdot 0$

$\cdot 5 \cdot 4$

$7 \cdot 1$

$10 \cdot 1$

$50 \cdot 0$

DDM concentration $\times 10^{4}$

(M)

$0 \cdot 87$

$1 \cdot 75$

$\mathbf{3} \cdot \mathbf{5}$

$6 \cdot 1$

$7 \cdot 0$

$8 \cdot 7$

$14 \cdot 0$

$17 \cdot 5$

A. Inhibition by DFP over $30 \mathrm{~min}$.

(Percentage)

\begin{tabular}{|c|c|c|c|}
\hline $\mathrm{ACh}$ & $\mathrm{BCh}$ & TB & $\mathbf{T A}$ \\
\hline- & - & $26 *, 27,27$ & - \\
\hline - & - & - & 20,29 \\
\hline - & $30,35,36,36$ & - & - \\
\hline 34, 34, 37 & - & $51,53,54^{*}$ & - \\
\hline- & $43,44,46,47$ & - & $\overline{-}$ \\
\hline $56, \overline{56}, 60$ & $60,61,65,67$ & $71, \overline{73^{*}}, 83$ & $\begin{array}{c}40,40 \\
-\end{array}$ \\
\hline- & - & - & $55,59,66$ \\
\hline 76 & $\overline{07}$ & $02 * \overline{01}$ & - \\
\hline $\begin{array}{c}83,89 \\
97\end{array}$ & $86,87,90$ & $83^{*}, 84,89$ & - \\
\hline - & - & - & 81 \\
\hline
\end{tabular}

B. Inhibition by DDM over $30 \mathrm{~min}$.

(Percentage)

\begin{tabular}{cccc}
\hline ACh & BCh & TB & TA \\
- & $18,20,21$ & $15,17,20$ & -120 \\
$11,13,13,16,18,19$ & $25,26,27,30,34$ & $22,26,28$ & $17,20,22$ \\
$29,33,33,34$ & 36,44 & $39,41,44,51$ & $33,34,34$ \\
45,47 & - & - & - \\
48 & - & $56,56,58,59$ & - \\
$52,54,56$ & - & -70 & $47,50,52$ \\
$59,63,64$ & - & - & $57,58,64$
\end{tabular}

Biochem. 1949, 44 
Table 4. $I_{50}$ values for $D D M$ and $D F P$

(Units: $y_{50}$ values, DFP series, $\mathrm{M}^{-1} \times 10^{-7}$; DDM series, $\mathrm{M}^{-1} \times 10^{-2} ; I_{50}$ values, DFP series, $\mathrm{M} \times 10^{9}$; DDM series, $\mathrm{M} \times 10^{4}$.)

\begin{tabular}{|c|c|c|c|c|c|c|c|c|}
\hline \multirow[b]{2}{*}{ Substrate } & \multirow{2}{*}{$\begin{array}{l}\text { No. of } \\
\text { obser- } \\
\text { vations }\end{array}$} & \multirow[b]{2}{*}{$y_{50}$} & \multirow{2}{*}{$\begin{array}{l}\text { Standard } \\
\text { error } \\
(8)\end{array}$} & \multicolumn{2}{|c|}{$\begin{array}{c}\text { Range of } y_{50} \\
\text { for which } P=0.2\end{array}$} & \multicolumn{3}{|c|}{$\begin{array}{c}I_{50} \text { values and limits outside which } \\
\text { less than } 20 \% \text { of estimates would } \\
\text { be expected to fall }\end{array}$} \\
\hline & & & & $\begin{array}{r}y_{50}+t s \\
\text { DFP }\end{array}$ & $y_{50}-t s$ & Upper. & $\begin{array}{c}\text { Most } \\
\text { probable }\end{array}$ & Lower \\
\hline $\begin{array}{l}\text { ACh } \\
\text { BCh } \\
\text { TB } \\
\text { TA }\end{array}$ & $\begin{array}{r}10 \\
15 \\
12 \\
8\end{array}$ & $\begin{array}{l}34 \cdot 85 \\
41 \cdot 47 \\
50 \cdot 50 \\
30 \cdot 42\end{array}$ & $\begin{array}{l}1 \cdot 898 \\
3 \cdot 345 \\
1 \cdot 706 \\
4 \cdot 690\end{array}$ & $\begin{array}{l}37 \cdot 50 \\
45 \cdot 99 \\
52 \cdot 84 \\
37 \cdot 06\end{array}$ & $\begin{array}{l}32 \cdot 20 \\
36 \cdot 95 \\
48 \cdot 16 \\
23 \cdot 78\end{array}$ & $\begin{array}{l}3 \cdot 11 \\
2 \cdot 71 \\
2 \cdot 08 \\
4 \cdot 21\end{array}$ & $\begin{array}{l}2 \cdot 87 \\
2 \cdot 41 \\
1 \cdot 98 \\
3 \cdot 29\end{array}$ & $\begin{array}{l}2 \cdot 67 \\
2 \cdot 18 \\
1 \cdot 89 \\
2 \cdot 70\end{array}$ \\
\hline $\begin{array}{l}\text { ACh } \\
\text { BCh } \\
\text { TB } \\
\text { TA }\end{array}$ & $\begin{array}{l}19 \\
11 \\
15 \\
12\end{array}$ & $\begin{array}{l}15 \cdot 31 \\
17 \cdot 41 \\
20 \cdot 67 \\
12 \cdot 48\end{array}$ & $\begin{array}{l}3 \cdot 264 \\
1 \cdot 194 \\
3 \cdot 321 \\
1 \cdot 803\end{array}$ & $\begin{array}{c}\text { DDM } \\
19 \cdot 66 \\
19 \cdot 06 \\
25 \cdot 15 \\
14.95\end{array}$ & $\begin{array}{l}10 \cdot 96 \\
15 \cdot 76 \\
16 \cdot 19 \\
10 \cdot 01\end{array}$ & $\begin{array}{l}9 \cdot 12 \\
6 \cdot 34 \\
6 \cdot 18 \\
9 \cdot 99\end{array}$ & $\begin{array}{l}6 \cdot 53 \\
5 \cdot 74 \\
4 \cdot 83 \\
8 \cdot 01\end{array}$ & $\begin{array}{l}5 \cdot 09 \\
5 \cdot 24 \\
3 \cdot 98 \\
6 \cdot 69\end{array}$ \\
\hline
\end{tabular}

Table 5. $I_{50}(D D M: D F P)$ ratios for $A C h$, $B C h, T B$ and $T A$

Most probable value of $I_{50}$ ratio $\left(\times 10^{-5}\right)$ and limits outside which less than $2 \%$ of estimates would be expected to fall

\begin{tabular}{|c|c|c|c|}
\hline Substrate & $\begin{array}{l}\text { Upper } \\
\text { limit }\end{array}$ & $\begin{array}{l}\text { Most probable } \\
\text { value }\end{array}$ & $\begin{array}{l}\text { Lower } \\
\text { limit }\end{array}$ \\
\hline $\begin{array}{l}\text { ACh } \\
\text { BCh } \\
\text { TB } \\
\text { TA }\end{array}$ & $\begin{array}{l}3 \cdot 42 \\
2 \cdot 92 \\
3 \cdot 26 \\
3 \cdot 70\end{array}$ & $\begin{array}{l}2 \cdot 28 \\
2 \cdot 38 \\
2 \cdot 44 \\
2 \cdot 44\end{array}$ & $\begin{array}{l}1.64 \\
1.94 \\
1.91 \\
1.59\end{array}$ \\
\hline
\end{tabular}

and inhibitor. This is illustrated in Table 6, in which the inhibition produced by $10^{-7} \mathrm{M}$-DFP on TB and TA hydrolysis is compared during an initial $10 \mathrm{~min}$. period and during a subsequent 20 min. period with the inhibition of ACh hydrolysis. It will be seen that the inhibition by DFP is by no means complete with the aliphatic substrates, though $10^{-8} \mathrm{M}$-DFP would probably have been sufficient to produce prompt and complete inhibition of ACh hydrolysis.

The time course of this inhibition of the aliphatic substrates closely parallels the time course of the TO esterase activity and suggests that the triolein enzyme may be responsible for the small amount of ali-esterase activity which escapes inhibition.

Summation experiments. Having concluded from our determinations of the $I_{50}$ ratios that one enzyme is mainly responsible for the hydrolysis of both aliphatic and choline esters, we sought confirmatory evidence by means of summation experiments.

A consideration of the kinetics of enzyme reactions with mixed substrates leads to the following conclusion. If two enzymes are present, each specific for one substrate, the rate of reaction of the mixed substrates will be equal to the sum of the rates of the separate reactions, provided neither substrate acts as an inhibitor of the other's enzyme. With a single non-specific enzyme, however, the rate of reaction of the mixed substrates will in no case exceed the greater of the rates of the separate reactions.

Table 6. Effect of $10^{-7} \mathrm{M}$ DFP on plasma esterase

\begin{tabular}{|c|c|c|c|c|c|}
\hline & $\begin{array}{r}(a=0 \\
\text { Acti } \\
\left(\mu \text { l. } \mathrm{CO}_{2} / \mathrm{m}\right.\end{array}$ & $\begin{array}{l}-10 \mathrm{~min} \\
\text { vity } \\
\text { l. plasm }\end{array}$ & $=10-3$ & nin.) & \\
\hline & (a) & & & Inhit & $(\%)$ \\
\hline Control & Inhibited & $\begin{array}{r}\text { Control } \\
\mathrm{ACh}\end{array}$ & $\begin{array}{l}\text { hibited } \\
02 \mathrm{M})\end{array}$ & (a) & (b) \\
\hline $\begin{array}{l}463 \\
507 \\
450 \\
465\end{array}$ & $\begin{array}{l}11 \\
0 \cdot 5 \\
0 \\
5\end{array}$ & $\begin{array}{l}528 \\
973 \\
900 \\
845\end{array}$ & $\begin{array}{l}3 \\
8 \\
8 \\
2\end{array}$ & $\begin{array}{c}97 \cdot 5 \\
100 \\
100 \\
99\end{array}$ & $\begin{array}{l}99 \cdot 5 \\
99 \\
99 \\
99 \cdot 5\end{array}$ \\
\hline & & TB & 1 м) & & \\
\hline $\begin{array}{l}113 \\
210 \\
200 \\
270\end{array}$ & $\begin{array}{l}13 \\
26 \\
10 \cdot 5 \\
22\end{array}$ & $\begin{array}{l}352 \\
415 \\
450 \\
400\end{array}$ & $\begin{array}{l}11 \\
11 \\
14 \\
13\end{array}$ & $\begin{array}{l}88 \\
88 \\
95 \\
88\end{array}$ & $\begin{array}{l}\mathbf{9 7} \\
\mathbf{9 7} \\
\mathbf{9 7} \\
\mathbf{9 7}\end{array}$ \\
\hline & & & 1 м) & & \\
\hline $\begin{array}{l}68 \\
71\end{array}$ & $\begin{array}{l}20 \\
22\end{array}$ & $\begin{array}{l}148 \\
157\end{array}$ & $\begin{array}{r}10 \\
1\end{array}$ & $\begin{array}{l}71 \\
69\end{array}$ & $\begin{array}{l}93 \\
99\end{array}$ \\
\hline
\end{tabular}

Table 7 shows the results of summation experiments carried out with ACh and TB, BCh and TB, and $\mathrm{BC}$ hand TA. Columns 3 and 4 give the rates of enzymic hydrolysis of $\mathrm{ACh}, \mathrm{BCh}, \mathrm{TB}$ and TA alone, column 5 that of the mixed substrates, $\mathrm{ACh}+\mathrm{TB}$, $\mathrm{BCh}+\mathrm{TB}$ or BCh $+\mathrm{TA}$. It will be seen that in each case the rate of hydrolysis of the mixed substrates is almost equal to the greater of the nates of hydrolysis of the single substrates, and is very much below the sum of these rates (column 6). These results confirm, therefore, the interpretation placed on the results of the inhibitor experiments, namely, that the aliesterase and cholinesterase activities of human plasma are mainly due to a single enzyme. 
Table 7. A comparison between the rates of hydrolysis of mixed aliphatic and choline ester substrates and those of the esters alone

(Concentration of plasma: TB experiments, $0.2 \mathrm{ml} . / 3 \mathrm{ml}$.; TA experiments, $0.5 \mathrm{ml} . / 3 \mathrm{ml}$.)

\begin{tabular}{|c|c|c|c|c|c|c|}
\hline \multicolumn{2}{|c|}{ Concentration (M) } & \multicolumn{5}{|c|}{ Rate of hydrolysis $\left(\mu \mathrm{l} . \mathrm{CO}_{2} / 30 \mathrm{~min}\right.$.) } \\
\hline $\begin{array}{l}\text { Choline } \\
\text { ester }\end{array}$ & $\begin{array}{l}\text { Aliphatic } \\
\text { ester }\end{array}$ & $\begin{array}{l}\text { Choline ester } \\
\qquad(a)\end{array}$ & $\begin{array}{c}\text { Aliphatic ester } \\
(b)\end{array}$ & $\begin{array}{l}\text { Mixed esters } \\
\quad(c)\end{array}$ & $(a+b)$ & $c$ less $a$ or $b$ \\
\hline & & & $\mathrm{ACh}+\mathrm{TB}$ & & & \\
\hline 0.006 & $0 \cdot 1$ & 232 & 155 & 246 & 387 & 14 \\
\hline 0.015 & $0 \cdot 1$ & 259 & 137 & 275 & 396 & 16 \\
\hline 0.03 & $0 \cdot 1$ & 268 & 142 & 288 & 410 & 20 \\
\hline 0.03 & $0 \cdot 1$ & 299 & 155 & 317 & 454 & 18 \\
\hline 0.03 & $0 \cdot 1$ & 314 & 147 & 319 & 461 & 5 \\
\hline 0.03 & $0 \cdot 1$ & 282 & 136 & 296 & 418 & 14 \\
\hline 0.03 & $0 \cdot 1$ & 288 & 148 & 300 & 436 & 12 \\
\hline & & & $\mathrm{BCh}+\mathrm{TB}$ & & & \\
\hline 0.006 & $0 \cdot 1$ & 111 & 129 & 144 & 240 & 15 \\
\hline 0.015 & $0 \cdot 1$ & 130 & 153 & 175 & 283 & 22 \\
\hline 0.03 & $0 \cdot 1$ & 125 & 140 & 147 & 265 & 7 \\
\hline & & & $\mathbf{B C h}+\mathbf{T A}$ & & & \\
\hline 0.03 & $0 \cdot 1$ & 312 & 151 & 337 & 463 & 25 \\
\hline 0.03 & $0 \cdot 1$ & 318 & 139 & 345 & 457 & 27 \\
\hline
\end{tabular}

It will be noted, however, that the values obtained for the rate of hydrolysis of the mixed substrates are slightly, but consistently, greater than the corresponding values for the greater of the rates of the single substrates.* The difference is recorded in the last column and indicates a small degree of positive summation. It suggests that at least $10 \%$ of the tributyrin esterase activity of the plasma and $17 \%$ of the triacetin activity is due to a second enzyme, and taken in conjunction with the low, but reproducible, activity of plasma towards triolein, and with the inhibition experiments with $10^{-7} \mathrm{M}-\mathrm{DFP}$, implies that the DFP-insensitive triolein esterase contributes to the total TB and TA esterase activity of plasma.

Further support for this view was obtained in summation experiments with tributyrin and triolein in the presence of a concentration of DFP sufficient to inhibit the DFP-sensitive esterase. The results recorded in Table 8 show that the DFP-insensitive hydrolysis of TB and TO is not additive, the sum of the rates of hydrolysis of TB and TO alone being much greater than the rate of hydrolysis of the mixed substrates. The presence of a small variable positive summation may be due partly to the difficulty of making accurate measurements with these low rates of $\mathrm{CO}_{2}$ evolution, and partly to the impossibility of knowing the exact concentration of DFP required to produce complete inhibition of the one enzyme while leaving the other unaffected.

* The effect is not obtained unless recently purified aliphatic esters are used. The significance of this is not clear; perhaps the aged esters contain an inhibitory substance as noted by Mendel \& Rudney (1943).
Table 8. A comparison, in the presence of $10^{-7} \mathrm{M}$ $D F P$, of the hydrolysis of a mixture of TB and TO with that of each substrate alone

(Concentration of substrates, $0.1 \mathrm{M}$.)

Rate of hydrolysis ( $\mu \mathrm{l} . \mathrm{CO}_{2} / \mathrm{ml}$. plasma/60 min.)

$\begin{array}{llcc}\text { TB } & \text { TO } & \text { Mixed } & \\ (a) & (b) & \text { substrates } & (a+b) \\ 54 & 51 & 60 & 105 \\ 52 & 70 & 73 & 122 \\ 48 & 62 & 84 & 110 \\ 32 & 53 & 56 & 85\end{array}$

The conclusion is thus strengthened that there exists in human plasma a small amount of a DFP. insensitive lipase-like enzyme which contributes to the total aliphatic esterase activity of the plasma.

\section{Experiments with purified plasma esterase}

Having demonstrated in our experiments with unpurified plasma that a DFP-insensitive lipase-like enzyme contributes significantly to its total aliphatic esterase activity, we next attempted to remove it by purification procedures. The method finally employed was ammonium sulphate fractionation at pH 6.

Procedure. All operations were carried out at $0 \pm 2^{\circ}$ to avoid the otherwise rapid inactivation of the preparations.

Sulphate and protein (as dry wt.) in active fractions were determined as follows. The fraction $(0.5 \mathrm{ml}$.) was pipetted into $15 \%(w / v)$ trichloroacetic acid and the mixture just brought to the boil. The protein precipitate was removed by filtration through paper and washed; the sulphate in the filtrate and washings was then determined gravimetrically 
as $\mathrm{BaSO}_{4}$. The protein precipitate was washed off the paper into the crucible on top of the $\mathrm{BaSO}_{4}$, the whole being redried and reweighed. $\left(\mathrm{NH}_{4}\right)_{2} \mathrm{SO}_{4}$ concentrations are recorded as percentages of the concentration of the saturated solution at $0^{\circ}(50 \% \mathrm{w} / \mathrm{v})$. The progress of the purification was checked by determining activity/mg. protein (dry wt.). A typical preparation was as follows.

Fresh human plasma $(200 \mathrm{ml}$.) was brought to $60 \%$ saturation by the addition during $2 \mathrm{hr}$. of an equal vol. of saturated $\left(\mathrm{NH}_{4}\right)_{2} \mathrm{SO}_{4}$ solution followed during a further hour by $21 \mathrm{~g}$. of solid $\left(\mathrm{NH}_{4}\right)_{2} \mathrm{SO}_{4}$. After standing overnight, the inactive precipitate was removed by centrifuging. The supernatant liquid was brought to $71 \%$ saturation by the slow addition of a further quantity of solid $\left(\mathrm{NH}_{4}\right)_{2} \mathrm{SO}_{4}$ and the mixture again allowed to stand overnight. A second precipitate, containing most of the enzymic activity, was collected by centrifuging and dissolved in glass-distilled water to $100 \mathrm{ml}$. After determining the concentration of $\left(\mathrm{NH}_{4}\right)_{2} \mathrm{SO}_{4}$ already present, more solid salt was gradually added to give $70 \%$ saturation. After $4 \mathrm{hr}$. the precipitate was collected and redissolved in water $(60 \mathrm{ml}$.). This procedure was repeated twice, the fraction appearing between 65 and $69.5 \%$ saturation being collected in the first reprecipitation and that between 66.5 and $69.5 \%$ in the second. The final preparation was taken up in water $\left(30 \mathrm{ml} \text {.), ( } \mathrm{NH}_{4}\right)_{2} \mathrm{SO}_{4}$ removed by dialysis and sufficient bicarbonate added to give $0.2 \%$ concentration.

Of the original activity $25-30 \%$ was present in the purified preparation, which had a cholinesterase activity/mg. protein (dry weight) 16-20 times that of the original plasma, and a negligible triolein esterase activity. Precipitation of the active fraction between 66.5 and $69.5 \%$ saturation, i.e. between the globulin and albumin fractions, accords with Vahlquist's (1935) cataphoresis experiments.

Inhibition experiments. Table 9 shows the effect of $10^{-7} \mathrm{M}$-DFP on the acetylcholine and tributyrin hydrolysis by a purified plasma esterase preparation. The results obtained with an unpurified portion of the same plasma are included for comparison. It will be seen that, whereas in the unpurified plasma (as in the more extended experiments of Table 6) the inhibitory effect of $10^{-7} \mathrm{M}-\mathrm{DFP}$ on the TB esterase activity is somewhat less than that on the ACh esterase activity during the first $10 \mathrm{~min}$. period, with the purified preparation, in which there is no triolein activity, the inhibition with both substrates is the same and essentially complete.

Summation experiments. The removal of the triolein esterase from plasma is also associated with the disappearance of the small degree of positive summation noted in a previous section when the rate of

Table 10. Summation experiments with aliphatic and choline esters

(Concentration of substrates: $\mathrm{ACh}$ and $\mathrm{BCh}, 0.03 \mathrm{M}$; TB and TA, 0.1 M.)

$$
\left.\mathrm{CO}_{2} \text { evolution ( } \mu \mathrm{l} . / 30 \mathrm{~min} .\right)
$$

\begin{tabular}{|c|c|c|c|}
\hline $\begin{array}{c}(a) \\
\text { Choline } \\
\text { ester }\end{array}$ & $\begin{array}{c}(b) \\
\text { Aliphatic } \\
\text { ester }\end{array}$ & $\begin{array}{c}(c) \\
\text { Mixed } \\
\text { esters }\end{array}$ & $(c-a)$ \\
\hline \multicolumn{4}{|c|}{ ACh + TB, unpurified plasma $(0.18 \mathrm{ml} . / 3 \mathrm{ml})}$. \\
\hline $\begin{array}{l}282 \\
288\end{array}$ & $\begin{array}{l}136 \\
148\end{array}$ & $\begin{array}{l}296 \\
300\end{array}$ & $\begin{array}{l}+14 \\
+12\end{array}$ \\
\hline \multicolumn{4}{|c|}{$\begin{array}{c}\mathrm{ACh}+\mathrm{TB}, \text { purified fraction from same plasma } \\
(0.15 \mathrm{ml} . / 3 \mathrm{ml} .)\end{array}$} \\
\hline $\begin{array}{l}276 \\
272 \\
277\end{array}$ & $\begin{array}{l}126 \\
120 \\
132\end{array}$ & $\begin{array}{l}276 \\
271 \\
275\end{array}$ & $\begin{array}{r}0 \\
-1 \\
-\quad 2\end{array}$ \\
\hline \multicolumn{4}{|c|}{$\mathrm{BCh}+\mathrm{TA}$, unpurified plasma $(0.5 . \mathrm{ml} . / 3 \mathrm{ml})}$. \\
\hline $\begin{array}{l}312 \\
318\end{array}$ & $\begin{array}{l}151 \\
139\end{array}$ & $\begin{array}{l}\mathbf{3 3 7} \\
\mathbf{3 4 5}\end{array}$ & $\begin{array}{l}+25 \\
+27\end{array}$ \\
\hline \multicolumn{4}{|c|}{$\mathrm{BCh}+\mathrm{TA}$, purified plasma $(0.5 \mathrm{ml} . / 3 \mathrm{ml})}$. \\
\hline $\begin{array}{l}317 \\
316 \\
328\end{array}$ & $\begin{array}{l}111 \\
105 \\
109\end{array}$ & $\begin{array}{l}313 \\
306 \\
320\end{array}$ & $\begin{array}{l}-4 \\
-10 \\
-8\end{array}$ \\
\hline
\end{tabular}

Table 9. A comparison, with unpurified and purified plasma esterases, of the inhibitory effect of $10^{-7} \mathrm{M}-D F P$ on $T B$ and $A C h$ hydrolysis

\begin{tabular}{|c|c|c|c|c|c|}
\hline \multicolumn{4}{|c|}{ Enzyme activity $\left(\mu \mathrm{l} . \mathrm{CO}_{2}\right)$} & & \\
\hline \multicolumn{2}{|c|}{$0-10 \mathrm{~min}}$. & \multicolumn{2}{|c|}{ 10-30 min. } & \multicolumn{2}{|c|}{ Inhibition (\%) } \\
\hline Control & Inhibited & Control & Inhibited & $0-10 \mathrm{~min}$. & 10-30 min \\
\hline \multicolumn{6}{|c|}{ A. Unpurified plasma ( $\mu \mathrm{l} . / \mathrm{ml})}$. \\
\hline \multicolumn{6}{|c|}{$\operatorname{ACh}(0.02 \mathrm{M})$} \\
\hline 450 & $\mathbf{0}$ & 900 & 8 & 100 & 99 \\
\hline 465 & 5 & 845 & 2 & 99 & 100 \\
\hline \multicolumn{6}{|c|}{ TB $(0 \cdot 1 \mathrm{M})$} \\
\hline 200 & 11 & 450 & 14 & 95 & 97 \\
\hline 270 & 22 & 400 & 13 & 88 & 97 \\
\hline \multicolumn{6}{|c|}{ B. Purified plasma ( $\mu \mathrm{l} . / \mathrm{ml}$. equiv.) } \\
\hline \multicolumn{6}{|c|}{ ACh $(0.02 \mathrm{M})$} \\
\hline 365 & $1 \cdot 5$ & 795 & 6 & $99 \cdot 5$ & 99 \\
\hline 505 & 2 & 860 & $\mathbf{3} \cdot \mathbf{5}$ & $99 \cdot 5$ & $99 \cdot 5$ \\
\hline \multicolumn{6}{|c|}{ TB $(0 \cdot 1 \mathrm{M}){ }^{3 \cdot 0}$} \\
\hline 185 & $\mathbf{1}$ & 325 & 6 & 100 & 98 \\
\hline 240 & 4 & 400 & 4 & $98 \cdot 5$ & 99 \\
\hline
\end{tabular}


hydrolysis of mixed aliphatic and choline esters is compared with the hydrolysis of the esters measured separately. Thus in Table 10 the rate of hydrolysis of $\mathrm{ACh}+\mathrm{TB}$ or TA and BCh + TB or TA is in all but one case actually less than that of $\mathrm{ACh}$ or $\mathrm{BCh}$ alone. Again, experiments performed with an untreated sample of the same plasma are included for comparison.

It will also be observed in Table 10 that, although the ACh and BCh activities of purified and unpurified plasmas are almost equal, the purified preparation is appreciably less active towards TB and TA, the fall being closely similar to that with the mixed esters.

\section{DISCUSSION}

Using human plasma as a source of non-specific esterase hydrolyzing both choline and non-choline esters, and two powerful esterase inhibitors, we have demonstrated that closely similar values for the ratio of the $I_{50}$ concentrations of these inhibitors are obtained with a representative range of substrates, although the $I_{50}$ values for each inhibitor vary considerably from one substrate to another. We believe, therefore, that a determination of the $I_{50}$ ratio may be useful as a means of characterizing enzymes in unpurified material, and of deciding in such cases whether a number of enzyme activities exhibited with different substrates are due to the same or to different enzymes.

In many respects the conditions we have chosen for our test are not ideal. Thus, in order to obtain an estimate of the range of $I_{50}$ values which there is a given probability of exceeding, it is necessary to make an assumption as to the form of the function relating the percentage inhibitions to the inhibitor concentration. The particular relation chosen (equation (1) above) appears to fit the experimental data over a wide middle range of inhibition, but is of a form which requires them to be plotted as reciprocals before they are amenable to statistical treatment. The method, therefore, suffers from the disadvantage that low percentage inhibitions, which are most subject to error, contribute most to the final positions of the lines of best fit.

It has already been pointed out that equation (1) implies the formation of a dissociable enzyme-inhibitor complex. There is some reason to believe that DDM is a competitive inhibitor (Thompson, 1947, using brain cholinesterase), and this implies the formation of a dissociable enzyme-inhibitor complex with the active centres of the enzyme; the kinetics of this inhibitor have not, however, been worked out fully, and it is possible that one of a number of products formed from it in solution is the actual inhibitor. DFP, on the other hand, is generally considered to be non-competitive, but this does not exclude the possibility of a dissociable complex, merely implying that the substrate does not compete with the inhibitor for the same groups in the enzyme and that the former cannot, therefore, exert a protective effect. Indeed, the recent work of Nachmansohn, Rothenberg \& Feld (1947) suggests that a DFP-enzyme complex can undergo dissociation.

The constants in equation (1) will include, for a competitive inhibitor, the affinity constant for the substrate and the substrate concentration. Thus if a competitive inhibitor is used in conjunction with a non-competitive inhibitor, changes in either the identity or the concentration of the substrate will, in principle, alter the $I_{50}$ ratio even if the enzyme alone is involved. The constancy of the ratio obtained in the present investigation suggests that with the particular system employed this effect is not contributing greatly to the result; and, bearing in mind the practical difficulties arising with insoluble aliphatic substrates and the disparate nature of the two inhibitors chosen, the concordance between the $I_{50}$ ratios appears promising.

Previous workers, in dismissing the small 'lipase' content of human plasma, have apparently overlooked the possibility that it might be responsible for a small but significant part of the aliphatic esterase activity; and our demonstration that this does in fact occur is a further complication in our test of the constancy of the $I_{50}$ ratio. Although these ratios for the various substrates are not significantly different with the order of accuracy obtained here, the most probable values for TB and TA are slightly higher than that for ACh. If we assume that none of the ACh hydrolysis, and about $10 \%$ of the TB and $20 \%$ of the TA hydrolysis (cf. Table 10), is due to the second esterase, and take the $I_{45}$ and $I_{40}$ ratios as a better estimate respectively of the true $I_{50}$ ratios for these substrates, we find that the values for both substrates now become identical with the value for ACh (Table 11). The effect is not, however, large because the second enzyme is insensitive to both inhibitors.

Table 11. Corrected $I_{50}$ values for $T B$ and $T A$

\begin{tabular}{|c|c|c|c|}
\hline Substrate & $\begin{array}{c}\text { Estimated \% } \\
\text { of total } \\
\text { hydrolysis due } \\
\text { to second enzyme }\end{array}$ & $\begin{array}{l}\text { Ratio } \\
\text { giving } \\
\text { true } I_{50} \\
\text { ratio }\end{array}$ & Value \\
\hline $\begin{array}{l}\text { ACh } \\
\text { TB } \\
\text { TA }\end{array}$ & $\begin{array}{r}0 \\
10 \\
20\end{array}$ & $\begin{array}{l}I_{50} \\
I_{45} \\
I_{40}\end{array}$ & $\begin{array}{l}2 \cdot 28 \\
2 \cdot 29 \\
2 \cdot 28\end{array}$ \\
\hline
\end{tabular}

An important limitation on the use of the $I_{50}$ ratio is therefore that it is not markedly affected by a second enzyme which contributes to the hydrolysis of one substrate but not another if this enzyme is unaffected by both inhibitors. Although no experiments have been carried out on the response of the $I_{50}$ ratio to the addition of a second enzyme such as a 'specific' cholinesterase which is sensitive to both 
inhibitors, there is little doubt that it would be great. It is thus possible that with a suitable choice of inhibitors the $I_{50}$ ratio method could be used to establish, first, whether the whole of the activity towards one substrate is identical with the activity towards another and, secondly, whether any part of it is.

So far, a purified preparation of the DFP-insensitive enzyme has not been obtained, and it is thus impossible to be certain of its exact specificity. It seems unlikely, however, that it can contribute to the ACh hydrolysis of plasma in view of the total inhibition produced in the unpurified preparation by very low DFP concentrations.

\section{SUMMARY}

1. Using human plasma as a source of a single nonspecific esterase and the cholinesterase inhibitors diisopropyl fluorophosphonate (DFP) and di-(2-chloroethyl)methylamine hydrochloride(DDM), a.method is described for characterizing the enzymic activity of the unpurified plasma towards representative choline and non-choline esters. This involves the determination for each substrate of the ratio of the concentrations of each inhibitor which produce $50 \%$ inhibition of hydrolysis (the DDM : DFP $I_{50}$ ratio). The method enables the most probable value of the ratio and the range of probable values to be estimated.

2. The values for the $I_{50}$ ratio for the different esters are closely similar, ranging from 2.28 to $2 \cdot 44 \times 10^{5}$.

3. The limitations of the method, and its possible wider application, are discussed.

4. Evidence has been obtained for the existence in human plasma of a small amount of a second enzyme, DFP-and DDM-insensitive, which accounts for 5-20\% (depending on the substrate) of the aliphatic esterase activity of the plasma, and which also hydrolyzes triolein.

5. When the $I_{50}$ ratios for tributyrin and triacetin are corrected for the contribution of the DFP. insensitive esterase they become identical with the value $\left(2.28 \times 10^{5}\right)$ for acetylcholine.

We are particularly indebted to $\mathrm{Dr}$ R. B. Fisher for his advice and helpful criticism, especially in connexion with the statistical aspect of our work. We are also grateful to Prof. R. A. Peters and Prof. R. H. S. Thompson for their interest. One of us (D.H.A.) wishes to thank the Department of Scientific and Industrial Research for a grant.

\section{REFERENCES}

Adams, D. H. \& Thompson, R, H. S. (1948). Biochem. J. $42,170$.

Ammon, R. (1933). Pflüg. Arch. ges. Physiol. 233, 486.

Easson, L. H. \& Stedman, E. (1937). Biochem. J. 31, 1723. Hanriot, M. (1898). Arch. Physiol. norm. path. (5), 10, 797. Mazur, A. \& Bodansky, O. (1946). J. biol. Chem. 163, 261. Mendel, B. \& Hawkins, R. D. (1947). Biochem. J. 41, P 22. Mendel, B., Mundell, D. B. \& Rudney, H. (1943). Biochem. J. 37, 473.
Mendel, B. \& Rudney, H. (1943). Biochem. J. 37, 59.

Nachmansohn, D., Rothenberg, M. A. \& Feld, E. A. (1947). Arch. Biochem. 14, 197.

Richter, D. \& Croft, P. G. (1942). Biochem. J. 36, 746.

Thompson, R. H. S. (1947). J. Physiol. 105, 370.

Thompson, R. H. S. \& Whittaker, V. P. (1944). Biochem. J. 38, 295.

Vahlquist, B. (1935). Skand. Arch. Physiol. 72, 133.

\section{Studies on Histaminase*}

\section{By R. KAPELLER-ADLER, Department of Pharmacology, University of Edinburgh}

\section{(Received 17 February 1948)}

In a number of papers Zeller and his co-workers (Zeller, 1938 $a, b$; Zeller, Birkhauser, Mislin \& Wenk, 1939; Zeller, Stern \& Wenk, 1940) have advanced evidence that histaminase acts on various diamines such as cadaverine, putrescine, agmatine and spermine, and have suggested that this enzyme should be called diaminoxidase. It has, however,

* Read in part before the Biochemical Society on 19 July 1946 (Kapeller-Adler, 1946). been found that the enzyme in placental extracts, and in the serum during pre-eclamptic toxaemia, differs from the enzyme in the serum during pregnancy in having much less effect on histamine compared with cadaverine (Kapeller-Adler, 1944). This suggested that there might after all be two enzymes and the question has, therefore, been reinvestigated by studying the effects of various conditions on $a$ purified preparation of the enzyme. 